\title{
TELAAH MEDIA ONLINE DALAM PROSES BELAJAR MENGAJAR (PBM) PENDIDIKAN AGAMA ISLAM (PAI) DI ERA PANDEMI COVID-19
}

\author{
Oleh : \\ Nanang Budianto ${ }^{1}$ \\ Muhsin $^{2}$
}

\begin{abstract}
ABSTRAK
Pembelajaran Pendidikan Agama Islam (PAI) di sekolah masih memerlukan pembenahan baik secara teknis, metode pengajaran, media serta yang berkaitan dengan Proses Belajar Mengajar Pendidikan Agama Islam (PAI) di sekolah, ketika dunia dihadapkan dengan pandemi yang melanda. Wabah VIRUS Covid-19 memberikan dampak terhadap pembelajaran Pendidikan Agama Islam (PAI) di Sekolah mulai tingkat PAUD sampai dengan tingkat SMA/MA/SMK. Kondisi demikian memaksa dunia pendidikan melakukan proses pembelajaran secara daring (online). Tujuan penulisan artikel ini untuk mempelajari dan memahami penggunaan media online dalam Proses Belajar Mengajar bidang study Pendidikan Agama Islam (PAI) di masa Pandemi Covid-19. Penggunaan media online di masa pandemi covid-19 ini menimbulkan berbagai tanggapan serta dampak dan perubahan sistem belajar yang dapat mempengaruhi proses Proses Belajar Mengajar (PMB) serta tingkat perkembangan peserta didik dalam merespon materi yang disampaikan.
\end{abstract}

Kata Kunci : Penggunaan media online, Bidang Study PAI, pandemi Covid-19.

\begin{abstract}
Learning Islamic Religious Education (PAI) in schools still requires improvement both technically, teaching methods, media and those related to the Islamic Religious Education Teaching and Learning Process (PAI) in schools, when the world is faced with a pandemic that hits. The Covid-19 VIRUS outbreak has an impact on learning Islamic Religious Education (PAI) in schools starting from the PAUD level to the SMA / MA / SMK level. This condition forces the education world to carry out the learning process online (online). The purpose of writing this article is to study and understand the use of online media in the Teaching and Learning Process of Islamic Religious Education (PAI) during the Covid-19 Pandemic. The use of online media during the Covid-19 pandemic caused various responses and impacts and changes in the learning system that could affect the Teaching and Learning Process (PMB) and the level of student development in responding to the material presented.
\end{abstract}

Keywords: Use of online media, Field of Study PAI, Covid-19 pandemic.

\footnotetext{
${ }^{1}$ Dosen Tetap Yayasan IAI Al Falaha As Sunniyyah Kencong Jember.

${ }^{2}$ Dosen Tetap Yayasan IAI Al Falaha As Sunniyyah Kencong Jember.

82 | Falasifa, Vol. 12 Nomor 1 Maret 2021
} 


\section{Nanang Budianto}

Muhsin

\section{A. PEndahuluan}

Dampak dari Pandemi Covid-19 pada aspek pendidikan adalah mengharuskan kegiatan belajar mengajar tetap berjalan meskipun peserta didik berada di rumah. Solusinya, pendidik dituntut mendesain media pembelajaran sebagai inovasi dengan memanfaatkan media daring (online). Hal Ini sesuai dengan keputusan Menteri Pendidikan dan Kebudayaan Republik Indonesia terkait Surat Edaran Nomor 4 Tahun 2020 tentang Pelaksanaan Kebijakan Pendidikan dalam Masa Darurat Penyebaran Covid-19.

Kondisi pandemi Covid-19 ini mengakibatkan perubahan yang luar biasa, seolah seluruh jenjang pendidikan 'dipaksa' bertransformasi untuk beradaptasi secara tiba-tiba untuk melakukan pembelajaran dari rumah melalui media daring (online). Ini tentu bukanlah hal yang mudah, karena belum sepenuhnya siap. Problematika dunia pendidikan yaitu belum seragamnya proses pembelajaran, baik standar maupun kualitas capaian pembelajaran yang diinginkan.

Hal ini tentu dirasa berat oleh pendidik dan peserta didik. Terutama bagi pendidik, dituntut kreatif dalam penyampaian materi melalui media pembelajaran daring. Ini perlu disesuaikan juga dengan jenjang pendidikan dalam kebutuhannya. Dampaknya akan menimbulkan tekanan fisik maupun psikis (mental).

Meskipun begitu, pemikiran yang positif, kreatif dan inovatif dapat membantu menerapkan media pembelajaran daring, sehingga menghasilkan capaian pembelajaran yang tetap berkualitas. Belajar di rumah dengan menggunakan media daring mengharapkan orang tua sebagai role model dalam pendampingan belajar anak serta dihadapi dengan perubahan sikap.

Sebagaimana firman Allah SWT

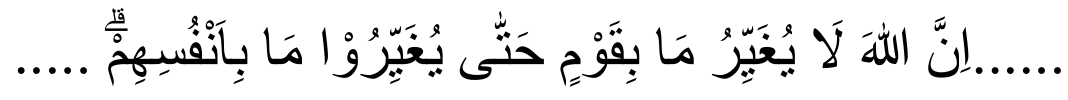

Artinya : Sesungguhnya Allah tidak akan mengubah keadaan suatu kaum sebelum mereka mengubah keadaan diri mereka sendiri. (QS. Ar-Ra'd: 11)³.

\section{B. PEMBAHASAN}

Agama Islam merupakan agama yang tidak menutup diri dengan pesatnya perkembangan zaman termasuk teknologi, namun justru agama Islam sangat fleksibel

\footnotetext{
${ }^{3}$ Alquran, $13: 11,2004$, hal. 226.
} 
bahkan menganjurkan umatnya untuk hidup dinamis dan berkembang menjadi lebih baik seiring dengan perkembangan zaman tersebut asalkan berlandaskan Iman dan Taqwa.

Berdasarkan kefektifan teknologi pembelajaran di atas serta dengan keterbukaan ajaran agama Islam dalam menerima hal-hal yang positif, maka sudah seharusnya pembelajaran Pendidikan Agama Islam (PAI) di sekolah dapat memanfaatkan media ini dan mulai mengubah model pembelajaran yang bersifat konvensional menjadi berbasis teknologi.

Oleh karena itu guru PAI di sekolah dituntut untuk mampu menciptakan inovasi teknologi pembelajaran yang relevan serta menerapkan model pembelajaran dengan pendekatan saintifik (scientific approach), pendekatan pembelajaran yang berpusat kepada siswa (student center), pembelajaran yang menekankan pada penilaian autentik (autentical evaluation), menerapkan model pembelajaran penemuan (discovery learning), pembelajaran berbasis proyek (project based learning) serta pembelajaran berbasis pemecahan masalah (problem based learning $)^{4}$.

Berbagai aplikasi media pembelajaran pun sudah tersedia, baik pemerintah maupun swasta. Pemerintah mengeluarkan Surat Edaran Menteri Pendidikan dan Kebudayaan Nomor 9/2018 tentang Pemanfaatan Rumah Belajar. Pihak swasta pun menyuguhkan bimbingan belajar online seperti ruang guru, Zenius, Klassku, Kahoot, dan lainnya. Aksesakses tersebut dapat dimanfaatkan untuk mengembangkan pengetahuan danwawasan. Sangat diperlukan peningkatan kualitas sumber daya manusia (SDM). Keberhasilan pembangunan negara salah satu tolak ukurnya adalah keberhasilan pendidikan.

Guru atau dosen bukan satu-satunya tonggak penentu. Ini tantangan berat bagi guru, dosen, maupun orang tua. Tak sedikit orangtua pun mengeluhkan media pembelajaran jarak jauh melalui daring (internet) ini. Terlebih bagi orangtua yang work from home(WFH), harus tetap mendampingi anak-anaknya, khususnya anaknya yang masih usia dini.

Ini mengingat belum meratanya diperkenalkan teknologi dalam pemanfaataan media belajar, seperti laptop, gadget, dan lainnya. Terutama anak usia dini hingga sekolah menengah belum merata ketersediaan fasilitas teknologi sebagai media belajar mengajar di sekolah. Meskipun sebagian besar sudah mengenal digital, sisi operasionalnya belum diterapkan optimal dalam media pembelajaran

Selain itu beberapa pendekatan pembelajaran dapat dikemas dalam program

\footnotetext{
${ }^{4}$ Heri Gunawan, Kurikulum Pembelajaran Pendidikan Agama Islam, Bandung : CV. ALVABETA, 2014, hal. 76. 84| Falasifa, Vol. 12 Nomor 1 Maret 2021
} 


\section{Nanang Budianto}

\section{Muhsin}

pembelajaran dengan menggunakan media komputer atau CAI (Computer Assisted Instruction), seperti: drill and practice, simulasi, problem solving, tutoial dan permainan. Pembelajaran dengan menggunakan media komputer dinilai tepat karena mempunyai beberapa kelebihan, yaitu: (1) dapat meningkatkan motivasi belajar siswa, (2) memberikan infomasi tentang kesalahan dan jumlah waktu belajar serta waktu untuk mengerjakan soalsoal kepada siswa, (3) mengatasi kelemahan pada pembelajaran kelompok, (4) melatih siswa untuk terampil memilih bagian-bagian isi pelajaran yang dikehendaki, (5) bermanfaat bagi siswa yang biasanya kurang dapat mengikuti metode pembelajaran konvensional, (6) mengurangi rasa malu dalam proses pembelajaran, (7) mendukung pembelajaran individual, (8) memungkinkan siswa untuk lebih mengenal dan terbiasa dengan komputer, (9) menciptakan pembelajaran yang enjoy, dan (10) komputer merupakan media penyampaian pembelajaran yang efektif 5 .

Hasil pengembangan produk e-learning berupa manajemen pembelajaran online melalui software aplikasi moodle versi 2.4 beberapa tahun lalu dengan alamat http://etkj.web.id. Kelayakan produk e-learning versi ini mendapatkan penilaian pada beberapa aspek dengan kategori baik, diantaranya; pada aspek media mendapatkan nilai 3.88 (kategori baik), pada aspek materi mendapatkan nilai 3.88 (kategori baik), dan aspek respon siswa mendapatkan nilai 3.64 (kategori baik). E-learning dengan pendekatan teori kognitif multimedia pembelajaran efektif meningkatkan hasil belajar siswa. Mobilitas teknologi semakin berkembang pesat, hingga aplikasi moodle sekarang semakin progress. Pembelajaran online dengan inovasi teknologi pada tahun ini menggunakan aplikasi moodle versi 3.8.1+ yang dirilis pada 30 januari 2020 yang lalu dengan alamat http://moodle.id.uptodown.com ${ }^{6}$.

\section{TEKNOLOGI PEMBELAJARAN PAI}

Pendidikan Agama Islam (PAI) merupakan salah satu mata pelajaran diberbagai jenjang sekolah termasuk perguruan tinggi memerlukan strategi dan teknik yang efektif serta dinamis dalam penyampaiannya guna memberikan kemudahan pemahaman bagi peserta didik. Salah satu pengembangan strategi dan teknik dalam pembelajaran PAI

\footnotetext{
5 Moch Fuad dan Anik Ghufron, Pengembangan Program CAI Dalam Pembelajaran PAI Materi Haji Dan Umrah Untuk Siswa Sekolah Tsanawiyah. Jurnal Inovasi Teknologi Pendidikan, 2014, vol. I, 2014, h. 85

6 https://www.dosenpai.com/2019/08/media-sosial-untuk-pai.html, Memanfaatkan Media Online dalam Pembelajaran PAI, diakses tanggal 15 Maret 2021.
} 
yakni dengan inovasi teknologi pembelajaran untuk mata pelajaran PAI tersebut ${ }^{7}$.

Pada pendahuluan diatas telah disebutkan bahwa Agama Islam ini fleksibel, tidak menutup serta membatasi diri dari perkembangan zaman. Hal ini disandarkan pada potongan sabda Rasulullah Saw sebagai berikut :

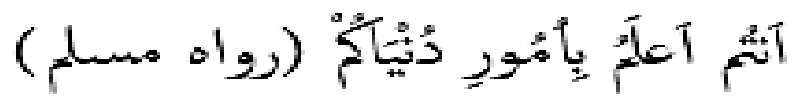

Artinya : "Engkau lebih mengetahui tentang urusan duniamu”. (H.R. Muslim).

Hadits ini terdapat dalam Shahih Muslim (1366) dimasukkan ke dalam bab dengan judul : “Bab Wajib Mengikuti Perkataan Nabi Shallallahu Alaihi Wa Sallam Dalam Masalah Syari'at Dan Yang Disebutkan Nabi Shallallahu 'Alaihi Wa Sallam Tentang Kehidupan Dunia Berdasarkan Pendapat", dan ini merupakan penyusunan bab yang sangat cermat.

Potongan hadits Nabi diatas menjelaskan bahwa Nabi Muhammad Saw tidak membatasi urusan dunia kepada para sahabat dan umatNya selagi urusan dunia itu maslahat, terlebih urusan dunia itu adalah untuk meningkatkan pembelajaran dalam dunia pendidikan melalui inovasi teknologi. Artinya ini sangat dianjurkan demi kemaslahatan proses pembelajaran dalam dunia pendidikan.

Teknologi pembelajaran didefinisikan sebagai bagian (subset) dari teknologi pendidikan dengan alasan bahwa instruksi (atau pembelajaran) merupakan bagian dari pendidikan yang bersifat terarah (purposive) dan terkendali (controlled) saja.

\section{PEMBELAJARAN PAI BERBASIS SOSIAL MEDIA ONLINE DAN WEB (E-}

\section{LEARNING)}

Sebelum merebahnya wabah covid-19, penggunaan media online khususnya sosial media pada jejaring internet, facebook, instagram dan website/blog sudah sangat pesat penggunanya diberbagai belahan dunia termasuk Indonesia. Media sosial merupakan sebuah wadah untuk memudahkan komunikasi antar pengguna. Hal ini sama halnya dengan apa yang dituliskan pada situs wikipedia yang menjelaskan bahwa media sosial itu adalah sebuah daring dengan para pengunjungnya bisa saling berpartisipasi, berbagi, dan lain sebagainya. Walaupun dengan jarak yang terbilang jauh, seseorang akan dapat saling terhubung dengan orang yang lain dengan waktu

\footnotetext{
${ }^{7}$ Abdul Majid dan Dian Andayani, Pendidikan Agama Islam Berbasis Kompetensi: Konsep dan Implementasi Kurikulum, Bandung : Rosdakarya, 2004, hal. 154. 


\section{Nanang Budianto}

\section{Muhsin}

yang singkat melalui media sosial. ${ }^{8}$

Pada sebuah sumber online (website/blog) menyebutkan bahwa pengguna sosial media di Indonesia pada tahun 2019 adalah sebagai berikut :

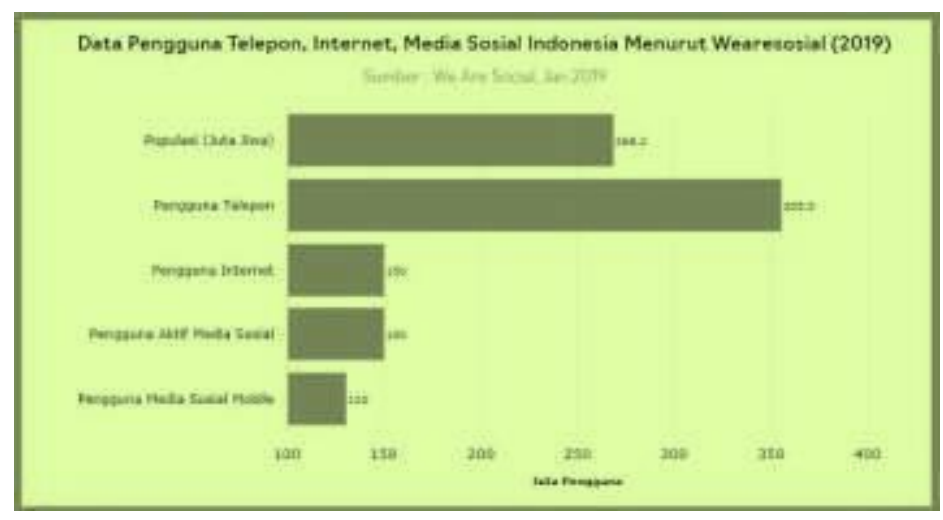

Gambar. 1

Grafik Pengguna Media Sosial di Indonesia Tahun 2019 (Sumber: http://www.katadata.co.id) ${ }^{9}$

Pada situs tersebut dijelaskan bahwa pengguna sosial media di Indonesia berjumlah $56 \%$ pengguna aktif dari total populasi. Ini adalah jumlah yang cukup besar bahkan lebih dari setengah masyarakat di Indonesia menggunakan sosial media.

Pendidikan Agama Islam (PAI) tentu menginginkan dan mendambakan pembelajaran yang aktif. Pembelajaran yang berlandaskan al-Quran dan Hadis itu tentu dipandang perlu dan wajib untuk dipelajari. Yang dikhawatirkan adalah pembelajaran PAI ini justru tenggelam dengan maraknya sosial media yang kini merenggut indahnya akhtivitas peserta didik. Salah satu sosial media yang sangat banyak penggunanya adalah jejaring sosial facebook.

Facebook merupakan sebuah layanan jejaring sosial yang berpusat di California, Amerika Serikat. Hal ini dikemukakan dalam situs Wikipedia bahwa facebook adalah sebuah layanan sosial media yang dirasa penggunanya sendiri cukup banyak. Kebanyakan orang akan mempublikasikan sesuatu dalam postingan di akun facebooknya yang biasa disebut status. Dalam rentetan waktu yang tidak terlalu lama, dalam sebuah halaman beranda facebook akan memunculkan suatu postingan terbaru

\footnotetext{
${ }^{8}$ LPPKSP Kemdikbud, Panduan Kepala Sekolah pada masa pandemi Covid-19, Html : Pengawas Disdik Kota Bandung. Jawa Barat, 2020, hal. 15.

${ }^{9}$ http://www.katadata.co.id, diakses tanggal 20 Pebruari 2021
} 
yang kian menit kian berubah ${ }^{10}$.

Sumber situs online menyebutkan bahwa pengguna sosial media facebook pada tahun 2019 adalah sebagai berikut :

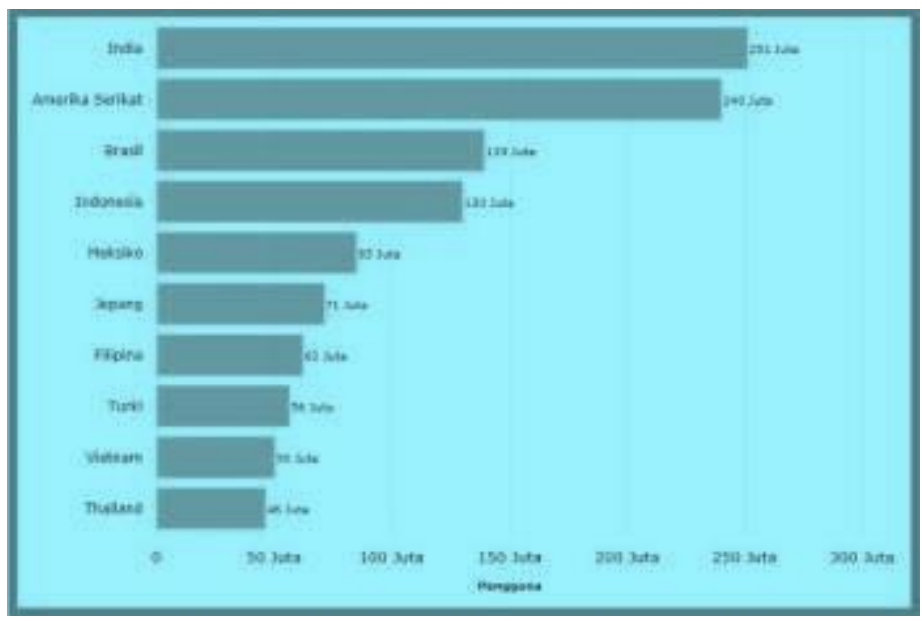

Gambar. 2

Grafik Pengguna Sosial Media Facebook Tahun 2019

(Sumber: http://www.katadata.co.id) $^{11}$

Jumlah terdahsyat yang ada pada bagian negara India. Pengguna facebook di India senilai lebih dari setengah pengguna di Indonesia. Data pada gambar di atas berdasarkan informasi pada situs website katadata.co.id. Data di atas menggambarkan seberapa banyak jumlah penduduk Indonesia yang menggunakan facebook. 130 juta akan terdengar sebagai jumlah yang sangat besar.

Pada tahun 2019, Indonesia memiliki populasi senilai 267 juta jiwa. Perbandingannya adalah antara jumlah populasi dengan jumlah pengguna facebook.

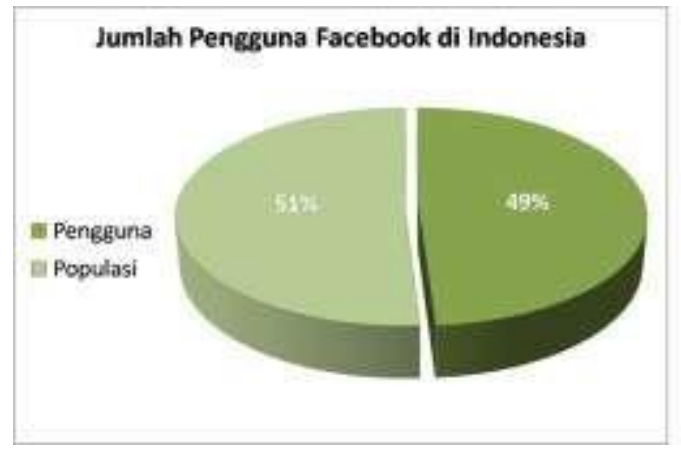

Gambar 3

Grafik Pengguna Media Sosial Facebook di Indonesia Tahun 2019

\footnotetext{
${ }^{10}$ Rusman, dkk, Pembelajaran Berbasis Teknologi Informasi Dan Komunikasi : Mengembangkan Profesionalitas Guru, Jakarta: PT. Raja Grafindo Persada, 2011, hal. 78.

${ }^{11}$ http://www.katadata.co.id, diakses tanggal 20 Pebruari 2021.

88| Falasifa, Vol. 12 Nomor 1 Maret 2021
} 


\section{Nanang Budianto}

Muhsin

\section{(Sumber: http://www.katadata.co.id) $)^{12}$}

Hampir mencapai separuh jumlah populasi jiwa di Indonesia adalah pengguna facebook. Tentu, ini angka yang dirasa cukup besar untuk satu sosial media di Indonesia, yaitu facebook. Itu hanya untuk satu sosial media saja. Sungguh angka yang luar biasa. Paling tidak, dari paparan data di atas, dapat digambarkan bahwa pengguna facebook di Kaitannya dengan artikel ini adalah ada beberapa hal yang perlu dilakukan oleh guru PAI berkenaan dengan penggunaan sosial media facebook guna tetap terselenggaranya pembelajaran.

Selain facebook, sosial media yang cukup banyak penggunanya adalah Instagram. Instagram bukanlah kata yang kita dengar. Instagram, merupakan sebuah layanan sosial dengan konten berbagi foto dan video yang belakangan ini cukup banyak penggunanya. Menurut wikipedia sendiri, instagram itu adalah sebuah aplikasi untuk membagikan foto dan video dalam jejaring sosial. Instagram digunakan kebanyakan orang untuk mempublikasikan sesuatu, baik itu sebuah produk yang ditawarkan, atau semacam unggahan video pribadi.

Pengguna instagram di Indonesia mencapai jumlah 53 juta pengguna. Ini angka yang lumayan besar, namun tidak sebanding dengan facebook.

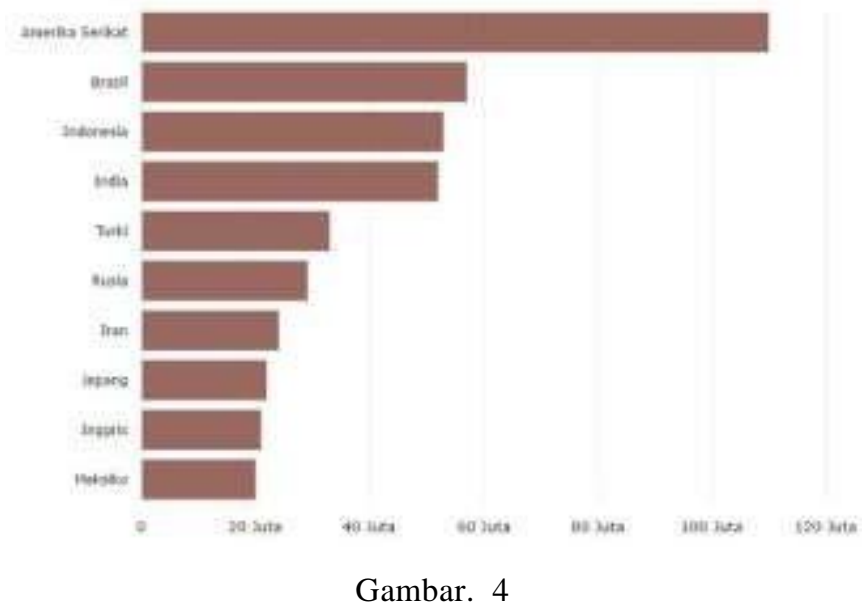

Grafik Pengguna Media Sosial Instagram di Indonesia Tahun 2019 (Sumber: http://www.katadata.co.id) ${ }^{13}$

Gambar diatas menjelaskan bahwa Instagram memiliki brandyang dikenal di Indonesia. Kebanyakan diantara mereka adalah dari kalangan

\footnotetext{
12 http://www.katadata.co.id, diakses tanggal 20 Pebruari 2021.

13 http://www.katadata.co.id, diakses tanggal 20 Pebruari 2021.
} 
remaja hingga dewasa. Waktu yang dibutuhkan guru PAI untuk mengajar di kelasnya hanya beberapa saat. Tetapi dengan sosial media seperti instagram, kamu dapat mengajar sesuai dengan waktu yang kamu inginkan.

\section{Konsep Pembelajaran Berbasis Web (E-Learning)}

Pembelajaran berbasis web merupakan suatu kegiatan pembelajaran yang memanfaatkan media situs (website) yang bisa diakses melalui jaringan internet. Pembelajaran berbasis web atau yang dikenal juga dengan "web based learning" merupakan salah satu jenis penerapan dari pembelajaran elektronik (e-learning). Elearning merupakan proses dan kegiatan penerapan pembelajaran berbasis web (web-based learning), pembelajaran berbasis komputer (computer based learning), kelas virtual (virtual classroom) dan/atau kelas digital (digital classroom) ${ }^{14}$.

Karakteristik e-learning sebagai berikut:

a. Interactivity (interaktivitas); tersedianya jalur komunikasi yang lebih banyak, baik secara langsung (synchrounus), seperti chatting atau messenger atau tidak langsung (asynchrounus), seperti forum, mailinglist atau buku tamu.

b. Independency (kemandirian); fleksibilitas dalam aspek penyediaan waktu, tempat, pengajar dan bahan ajar. Hal ini menyebabkan pembelajaran menjadi lebih terpusat kepada siswa (student-centered learning).

c. Accessibility (aksesibilitas); sumber-sumber belajar menjadi lebih mudah diakses melalui pendistribusian di jaringan internet dengan akses yang lebih luas daripada pendistribusian sumber belajar pada pembelajaran konvensional.

d. Enrichment (pengayaan); kegiatan pembelajaran, presentasi materi kuliah dan materi pelatihan sebagai pengayaan, memungkinkan penggunaan perangkat teknologi informasi seperti video streaming, simulasi dan animasi $^{15}$.

\section{Fungsi Dan Manfaat Pembelajaran Berbasis Web}

Pembelajaran berbasis web bisa menjadi pembelajaran yang menyenangkan, memiliki unsur interaktivitas yang tinggi, menyebabkan peserta didik mengingat lebih banyak materi pelajaran, serta mengurangi biaya-biaya operasional yang

\footnotetext{
${ }^{14}$ Eric Jensen, Brain-Based Learning, Yogyakarta : Pustaka Belajar, 2008, hal. 190.

${ }^{15}$ Salwa Dewi Prawiradilaga dan Eveline Siregar, Mozaik Teknologi Pendidikan, Jakarta: Kencana, 2017, hal. 75.

90| Falasifa, Vol. 12 Nomor 1 Maret 2021
} 


\section{Nanang Budianto}

\section{Muhsin}

biasanya dikeluarkan oleh peserta didik untuk mengikuti pembelajaran (contohnya uang jajan/biaya transportasi sekolah). Dikarenakan sifatnya yang maya/virtual, pembelajaran berbasis web dianggap telah memberikan fleksibilitas terhadap kegiatan pengaksesan materi pembelajaran.

\section{Prinsip-Prinsip Pembelajaran Berbasis Web}

Setidaknya prinsip yang harus ada dalam pembelajaran berbasis web adalah:

a. Interaksi

Dalam lingkungan belajar, interaksi berarti kapasitas berbicara baik antarpeserta, maupun antara peserta dengan instruktur. Interaksi tidak hanya menyediakan hubungan antarmanusia, tetapi juga menyediakan keterhubungan isi, di mana setiap orang dapat saling membantu antara satu dengan yang lainnya untuk memahami isi materi dengan berkomunikasi.

b. Ketergantungan

Ketergantungan yang dimaksud adalah bagaimana siswa mudah menggunakan web. Terdapat dua elemen penting dalam prinsip ketergantungan ini, yaitu konsistensi dan kesederhanaan. Intinya adalah bagaimana pengembang pembelajaran berbasis web ini menciptakan lingkungan belajar yang konsisten dan sederhana, sehingga siswa tidak mengalami kesulitan baik dalam proses pembelajaran maupun navigasi konten (materi dan aktivitas belajar lain).

c. Kesesuaian

Relevansi diperoleh melalui ketepatan dan kemudahan. Setiap informasi dalam web hendaknya dibuat sangat spesifik untuk meningkatkan pemahaman pembelajar dan menghindari bias. Menempatkan konten yang relevan dalam konteks yang tepat pada waktu yang tepat adalah bentuk seni tersendiri, dan sedikit pengembangan elearning yang berhasil melakukan kombinasi ini. Hal ini melibatkan aspek keefektifan desain konten serta kedinamisan pencarian dan penempatan konten

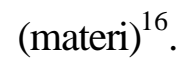

\section{Pemanfaatan E-learning Untuk Pembelajaran}

"E" atau singkatan dari elektronik dalam e-learning digunakan sebagai istilah untuk segala teknologi yang digunakan untuk mendukung usaha-

\footnotetext{
${ }^{16}$ B. Hamzah dan Nina Lamatenggo, Teknologi Komunikasi Dan Informasi Pembelajaran, Jakarta : Bumi Aksara, 2010, hal. 85.
} 
usaha pembelajaran lewat teknologi elektronik internet. Internet, intranet, satelit, tape audio/video, TV interaktif dan CD-ROM adalah sebagian dari media elektronik yang digunakan pembelajaran boleh disampaikan secara 'synchronously' (pada waktu yang sama) ataupun 'asynchronously' (pada waktu yang berdeba). Materi pembelajaran dan pembelajaran yang disampaikan melalui media ini mempunyai teks, grafik, animasi, simulasi, audio, dan video. Ia juga harus menyediakan kemudahan untuk 'discussion group' dengan bantuan professional dalam bidangnya ${ }^{17}$.

Perbedaan pembelajaran tradisional dengan e-learning, yaitu kelas 'tradisional', guru dianggap sebagai orang yang serba tahu dan ditugaskan untuk menyalurkan ilmu pengetahuan kepada pelajarnya. Sedang di dalam pembelajaran 'e-learning' fokus utamanya adalah pelajar. Pelajar mandiri pada waktu tertentu dan bertanggungjawab untuk pembelajarannya. Suasana pembelajaran 'e-learning' akan 'memaksa' pelajar memainkan peranan yang lebih aktif dalam pembelajarnya. Pelajar membuat perancangan dan mencari materi dengan usaha, dan inisiatif sendiri.

\section{Pengembangan Model E-Learning}

Ada tiga kemungkinan dalam pengembangan sistem pembelajaran berbasis internet, yaitu : web course, web centric course, dan web enched course.

a. Web course adalah penggunaan internet untuk keperluan pendidikan, yang mana mahasiswa dan dosen sepenuhnya terpisah dan tidak diperlukan adanya tatapmuka.

b. Web centric course adalah penggunaan internet yang memadukan antara belajar jarak jauh dan tatap muka (konvensional). Sebagian materi disampaikan melalui internet, dan sebagian lagi melalui tatap muka.

c. Web enhanced course adalah pemanfaatan internet untuk menunjang peningkatan kualitas pembelajaran yang dilakukan di kelas $^{18}$.

\section{KESIMPULAN}

Agama Islam merupakan Agama yang tidak jumud (statis) artinya Agama Islam ini

\footnotetext{
${ }^{17}$ Salwa Dewi Prawiradilaga, Wawasan Teknologi Pendidikan, Jakarta : Kencana Prenada Media Group, 2012, 135.

${ }_{18}$ Rusman, dkk, Pembelajaran Berbasis Teknologi Informasi Dan Komunikasi: Mengembangkan Profesionalitas Guru, Jakarta: PT. Raja Grafindo Persada, 2011, hal. 147.

92| Falasifa, Vol. 12 Nomor 1 Maret 2021
} 


\section{Nanang Budianto}

Muhsin

dinamis terlihat dari keterbukaannya dalam segala bidang yang memberikan kemaslahatan kepada umat. Agama Islam tidak menutup dan membatasi diri dengan pesatnya perkembangan zaman, agama Islam justru sangat fleksibel bahkan menganjurkan umatnya untuk hidup maju dan berkembang menjadi lebih baik ditengah-tengah era digital serta melek teknologi ini selama berlandaskan Iman dan Taqwa, termasuk pada situasi pandemi saat ini.

Pandemi Covid-19 memang memberikan dampak yang signifikan diberbagai aspek terutama pendidikan, namun situasi ini tidak menjadikan surut semangat para pendidik dan peserta didik untuk tetap melaksanakan kegiatan belajar mengajar secara daring (Online). Dengan teknologi yang semakin cangging di era revolusi industry 4.0 ini berbagai media online menjadi sebuah jalan guna tetap terlaksananya pendidikan. Pendidikan, khususnya kita sebagai pendidik yang merupakan salah satu komponennya harus bisa menyesuaikan dan memanfaatkan teknologi tersebut untuk kepentingan belajar, karena tidak dapat dipungkiri dengan berkembangnya teknologi itu unsur negatif pun banyak. 


\section{DAFTAR PUSTAKA}

Alquran, $13: 11,2004$.

Abdul Majid dan Dian Andayani, Pendidikan Agama Islam Berbasis Kompetensi: Konsep dan Implementasi Kurikulum, Bandung : Rosdakarya, 2004.

B. Hamzah dan Nina Lamatenggo, Teknologi Komunikasi Dan Informasi Pembelajaran, Jakarta : Bumi Aksara, 2010.

Eric Jensen, Brain-Based Learning, Yogyakarta: Pustaka Belajar, 2008.

Heri Gunawan, Kurikulum Pembelajaran Pendidikan Agama Islam, Bandung : CV. ALVABETA, 2014.

http://www.katadata.co.id, diakses tanggal 20 Pebruari 2021.

https://www.dosenpai.com/2019/08/media-sosial-untuk-pai.html, Memanfaatkan Media Online dalam Pembelajaran PAI, diakses tanggal 15 Maret 2021.

LPPKSP Kemdikbud, Panduan Kepala Sekolah pada masa pandemi Covid-19, Html : Pengawas Disdik Kota Bandung. Jawa Barat, 2020.

Moch Fuad dan Anik Ghufron, Pengembangan Program CAI Dalam Pembelajaran PAI Materi Haji Dan Umrah Untuk Siswa Sekolah Tsanawiyah. Jurnal Inovasi Teknologi Pendidikan, Jurnal Keislaman, Vol. I, 2014.

Rusman, dkk, Pembelajaran Berbasis Teknologi Informasi Dan Komunikasi : Mengembangkan Profesionalitas Guru, Jakarta: PT. Raja Grafindo Persada, 2011.

Salwa Dewi Prawiradilaga, Wawasan Teknologi Pendidikan, Jakarta : Kencana Prenada Media Group, 2012.

Salwa Dewi Prawiradilaga dan Eveline Siregar, Mozaik Teknologi Pendidikan, Jakarta: Kencana, 2017. 
Nanang Budianto

Muhsin

Falasifa, Vol. 12 Nomor 1 Maret 2021 | 95 